\title{
BIPOLAR TRANSURETHRAL RESECTION OF PROSTATIC ADENOMAS LARGER THAN 60CC: SAFETY AND EFFICACY
}

\author{
By \\ El-Sayed G. El-Shahawy, Ali M. H. Farag, Ahmed F. Abd El-Rahim* \\ and Gamal T. El-Shayal
}

Department of Urology, Faculty of Medicine (Cairo* and Damietta), Al-Azhar University

Corresponding author: El-Sayed G. El-Shahawy,

Mobile: +201121909264, E-mail: sgad34368@gmail.com

\begin{abstract}
Background: The plasma kinetic technique that enables resection of the entire lobes of the prostate with physiologic saline irrigation seems to be a new option among minimally invasive surgical technique.

Objective: To evaluate safety and efficacy of plasma kinetic resection of prostatic adenomas larger than 60 cc for symptomatic BPH.

Patients and methods: It included 50 patients, from Al-Azhar university hospitals. They were submitted to full history taking, examination, and investigations before and after plasma kinetic resection of the prostate.

Results: In the studied group preoperative Q-max ranged from 3.4 to13 with a mean of 7.60 \pm 2.80 in patients presented with LUTS, while after intervention, it ranged from 14.1 to18.58 with a mean of $17.10 \pm 0.89$; and a mean of $17.37 \pm 0.93$ in patients with retention. There was significant increase after TURIS. IPSS score before intervention ranged from 16 to 30 with a mean of 21.94 44.36 ; while after intervention, it ranged from 2 to 16 with a mean of $8.82 \pm 4.06$ and there was significant decrease after intervention. Quality of life score before intervention ranged from 3 to 6 with a mean of 4.46 \pm 1.16 ; while after intervention, it ranged from 1 to 4 with a mean of $1.74 \pm 0.82$ and there was significant decrease after intervention in comparison to their values before intervention.
\end{abstract}

Conclusion: Plasma kinetic resection of the prostate provides a reasonable, safe and effective procedure for treatment benign prostatic hyperplasia.

Keywords: Bipolar; Prostate; Adenoma; Outcome; Resection.

\section{INTRODUCTION}

Benign prostatic hyperplasia $(\mathrm{BPH})$ is the most common cause of lower urinary tract symptoms in older men (Oelke et al., 2013). Medical therapy is the first line of treatment of BPH but a significant percentage of those patients will require surgical intervention (Reich et al., 2010). Until now, transurethral resection of the prostate (TURP) remains the gold standard for treatment of BPH due to its safe, effective, and durable outcomes. Nevertheless, the perioperative morbidity from TURP remains considerable, including postoperative bleeding, TUR syndrome, urethral stricture, and so on (Zhong et al., 2019). Also, the management of patients with large prostate volumes $>80 \mathrm{cc}$ presents a challenge. The AUA and (EAU) guidelines suggest that open prostatectomy should be the treatment of 
choice in patients with prostate volumes 80-100 mL (Teng et al., 2013, AUA, 2003).However, open prostatectomy for large prostates has been progressively decreasing over the years with the advent of minimally invasive techniques, including monopolar and bipolar TURP, vaporization techniques (Han et al., 2014).

The transurethral plasma kinetic resection of the prostate (PKRP) is a minimally invasive technique for $\mathrm{BPH}$ surgery in which resection of tissue by creating an ionized plasma corona using an axipolar electrode and electro conductive solutions (Han et al., 2014 and Cornu et al., 2015). In the PKRP using saline as an irrigant rather than glycine or sorbitol minimizes the risks of transurethral resection (TUR) syndrome, which is great concern during TURP ( $\mathrm{Cao}$ et al., 2019).

The aim of this study was to evaluate safety and efficacy of bipolar transurethral plasma kinetic resection of prostatic adenomas more than $60 \mathrm{cc}$ for treatment of symptomatic BPH.

\section{PATIENTS AND METHODS}

This study was a prospective selfcontrolled clinical trial that was carried out at Al-Azhar University hospital (Damietta), during the period from January 2015 to January 2018. It included 50 patients with symptomatic benign prostatic hyperplasia.

\section{Inclusion criteria:}

Patients older than 50 years, Prostatic adenoma more than $60 \mathrm{cc}$, At least 3month duration of symptomatic BPH, persistence or progression of voiding symptoms in spite of receiving appropriate medications for at least 3 months, and patients in retention who failed to be weaned from their catheters after one-week course of alpha blockers.

\section{Exclusion criteria:}

Patients with neurogenic insult that may induce bladder or outlet dysfunction, proved prostatic carcinoma, Bladder pathologies (retentive diverticulumstones), Urethral stricture, Previous prostatic or urethral surgeries and patients with comorbidities that may render them high surgical risk.

\section{Preoperative assessment:}

A. Laboratory investigations:

- Routine laboratory investigations as $\mathrm{CBC}$, blood sugar, liver function (SGOT, SGPT), renal function test (serum creatinine) and coagulation profile (prothrombin time and concentration, INR).

- Specific laboratory investigations as urine analysis, urine culture and sensitivity tests in cases with UTI as well as PSA estimation (free and total).

\section{Imaging studies including:}

Abdomino-pelvic ultrasonography with estimation of the post-voiding residual urine (PVR) and Transrectal ultrasonography (TRUS).

E. Uroflowmetry for voiding patients: Pressure flow studies were performed for patients with initial evaluation suggesting bladder dysfunction rather than $\mathrm{BPH}$.

Operative procedure: After preliminary diagnostic cystoscopy, Plasma kinetic transurethral vaporization was performed 
using the Plasma Kinetic ${ }^{\mathrm{TM}}$ Super Pulse system, consisting of a $\mathrm{PK}^{\circledR}$ generator, a PK resectoscope and a Plasma-Sect ${ }^{\circledR}$ electrode by AUTOCON II 400 high end supply voltage (Storz Inc. ${ }^{\circledR}$ Germany). Power was maintained at the default setting (level 4 vaporization and level 4 coagulation) equal to $200 \mathrm{~W}$ normal saline $(0.9 \%)$ was used as irrigant fluid.

Resection was started at the middle lobe to create a working space from the bladder neck to the verumontanum, the two lateral lobes were then resected starting from upper border of the right lobe then the left one, the bleeding points were controlled with the coagulation setting at $200 \mathrm{~W}$.

A 22 Fr three-way Foley catheter with $100 \mathrm{cc}$ balloon was inserted with continuous post-operative saline irrigation maintained till become clear.

Preoperative and intraoperative
evaluation and recording of the
findings: Resection time, electrolytes $(\mathrm{Na}$
$\mathrm{K} \mathrm{Cl}$ ) before anesthesia, amount of
irrigation fluid used, hemodynamic status,
and any intra-operative complications.

Early Postoperative evaluation: Complete blood picture and serum electrolytes 6 hours postoperative, amount and duration of irrigation used, duration of catheterization, hospital stay, blood transfusion, and any postoperative complications.

Follow up: After 1 week, 3, 6 months and 1 year respectively according to the following schedule.

\section{Statistical analysis of data:}

The collected data were organized, tabulated and statistically analyzed using statistical package for social science (SPSS) version $20 \quad\left(\mathrm{IBM}^{\circledR} \mathrm{SPSS}^{\circledR} \quad\right.$ Inc, USA), running on IMB compatible computer with Microsoft ${ }^{\circledR}$ Windows 10. For qualitative data, frequency and percent distributions were calculated, while quantitative data were represented as mean and standard deviations. For comparison between values before surgical intervention using ANOVA with post-hoc test and the same variables after intervention. For interpretation of results, $p$ value $\leq 0.05$ was considered significant.

\section{RESULTS}

The operative time ranged from 60 to 120 minutes; the mean \pm SD values were $94.18 \pm 18.54$ minutes. The irrigation volume ranged from 10 to 40 liters and the mean values \pm SD were $25.34 \pm 7.86$. Intraoperative complications were reported in two patients (one of subtrigonal resection and the other of conversion to open surgery to drain bladder perforation and procedure was finished), the duration of hospital stay ranged from 3 to 4 days (mean $\pm \mathrm{SD}$ was $3.56 \pm 0.50$ days), while the urethral catheter duration ranged from 2 to 5 days, the mean \pm SD values were $3.32 \pm 1.20$ days, dysuria was the most common early postoperative complications $(70 \%)$ of patients, retention and temporary urge incontinence in $(2 \%)$, while infection reported in $(3 \%)$ of patients. Late postoperative complications were reported in 2 patients (4\%), one presented with stricture urethra while the other one presented with obstructing residual adenoma that needed retreatment (Table 1). 
Table (1): Patient demographics and preoperative data

\begin{tabular}{|c|c|c|c|c|}
\hline \multicolumn{2}{|c|}{ Variables Cases No $=50]$} & Mean & SD & Range \\
\hline \multicolumn{2}{|l|}{ Age } & 66.28 & 6.19 & $55-80$ \\
\hline \multicolumn{2}{|l|}{ IPSS } & 21.94 & 4.36 & 16.30 \\
\hline \multicolumn{2}{|l|}{ QoL } & 4.46 & 1.16 & $3-6$ \\
\hline & & \multicolumn{2}{|c|}{ No } & $\%$ \\
\hline \multirow{2}{*}{$\begin{array}{l}\text { Presenting } \\
\text { Symptoms }\end{array}$} & Obstructive symptoms & \multicolumn{2}{|c|}{25} & $50.0 \%$ \\
\hline & Refractory urine retention & \multicolumn{2}{|c|}{25} & $50.0 \%$ \\
\hline \multirow{4}{*}{$\begin{array}{l}\text { Associated } \\
\text { Medical } \\
\text { Comorbidities }\end{array}$} & Hypertension & \multicolumn{2}{|c|}{35} & $70 \%$ \\
\hline & DM & \multicolumn{2}{|c|}{10} & $20 \%$ \\
\hline & IHD & \multicolumn{2}{|c|}{2} & $4 \%$ \\
\hline & Liver disease & \multicolumn{2}{|c|}{11} & $22 \%$ \\
\hline \multirow{7}{*}{$\begin{array}{l}\text { Laboraty } \\
\text { findings }\end{array}$} & PSA & 3.98 & 2.63 & $0.3-8$ \\
\hline & Serum creatinine & 1.14 & 0.33 & $0.6-1.6$ \\
\hline & AST & 38.08 & 13.77 & 12- 69 \\
\hline & SLT & 27.68 & 21.60 & $10-85$ \\
\hline & Random blood sugar & 184.54 & 96.63 & $82.0-370$ \\
\hline & Hemoglobin & 13.31 & 1.70 & $10.20-15.80$ \\
\hline & Hematocrit & 51.3 & 2.32 & $48-55$ \\
\hline \multicolumn{2}{|c|}{ Size of adenoma } & 68.18 & 6.2 & $60-80$ \\
\hline \multicolumn{2}{|l|}{ Qmax } & 7.60 & 2.80 & 3.4- 13 \\
\hline \multicolumn{2}{|l|}{ PVR } & 324.30 & 167.50 & $70-600$ \\
\hline
\end{tabular}

Preoperative Q max ranged from 3.4 to 13 and there was statistically significant increase at 3,6 and 12 months $(17.39 \pm 0.90,17.10 \pm 0.87$ and $17.10 \pm 0.89$ respectively) when compared to preoperative values $(7.60 \pm 2.80)$. In addition, preoperative voiding residual urine ranged from 70 to $600 \mathrm{ml}$; and there was statistically significant decrease at 3 , 6 and 12 months $(85.68 \pm 40.78$, $59.06 \pm 34.03$ and $48.50 \pm 29.05$ respectively) when compared to preoperative values (Table 2).

Table (2): The patient's preoperative and postoperative Laboratory data

\begin{tabular}{|l|c|c|c|c|c|}
\hline \multirow{2}{*}{ Data } & \multicolumn{2}{|c|}{ Preoperative (50) } & \multicolumn{2}{c|}{ Postoperative (50) } & P \\
\cline { 2 - 5 } Parameters & Range & Mean \pm SD & Range & Mean \pm SD & value \\
\hline $\mathrm{Na}(\mathrm{mmol} / \mathrm{L})$ & $133-148$ & $140.5 \pm 4.21$ & $130-146$ & $141.5 \pm 3.42$ & 0.001 \\
\hline $\mathrm{K}(\mathrm{mmol} / \mathrm{L})$ & $3.4-5.3$ & $4.32 \pm 0.66$ & $2.7-5.8$ & $4.25 \pm 0.76$ & 0.25 \\
\hline $\mathrm{Cl}(\mathrm{mmol} / \mathrm{L})$ & $98-106$ & $101.74 \pm 2.52$ & $80-120$ & $101.58 \pm 12.26$ & 0.92 \\
\hline $\mathrm{Hb}(\mathrm{g} / \mathrm{dl})$ & $10.20-15.80$ & $13.31 \pm 1.70$ & $8.0-14.50$ & $12.46 \pm 1.22$ & 0.001 \\
\hline $\mathrm{Hct}(\%)$ & $48-55$ & $51.3 \pm 2.32$ & $40-52$ & $49.10 \pm 2.68$ & 0.001 \\
\hline
\end{tabular}

There was statistically significant decrease of international prostate symptoms score (IPSS) at 3, 6 and 12 months postoperatively (11.12 \pm 7.92 , $9.86 \pm 5.34$ and $8.82 \pm 4.06$ respectively) when compared to preoperative values (21.94 \pm 4.36$)$. In addition, preoperative quality of life index ranged from 3 to 6 , the mean value was $4.46 \pm 1.16$. At 3 months postoperatively, the index ranged from 1 to 6 , while at 6 months postoperatively, it ranged from 1- 4 and at 12 months postoperatively, it ranged from $1-4$; and there was statistically significant 
decrease of QoL index at 3, 6, 12 months $(2.76 \pm 1.36, \quad 1.92 \pm 1.02$ and $1.74 \pm 0.82$ preoperative values $(4.46 \pm 1.16)$ (Table respectively) when compared to 3).

Table (3): Outcome among patients of the study

\begin{tabular}{|c|c|c|c|c|c|c|c|c|c|}
\hline \multirow[b]{2}{*}{ Parameters } & \multicolumn{4}{|c|}{$\begin{array}{c}\text { Patients originally with obstructive } \\
\text { LUTS }(n=25)\end{array}$} & \multicolumn{3}{|c|}{$\begin{array}{l}\text { Patients originally in } \\
\text { retention }(n=25)\end{array}$} & \multicolumn{2}{|c|}{ ANOVA } \\
\hline & $\begin{array}{c}\text { Pre- } \\
\text { operative }\end{array}$ & $\begin{array}{c}\text { At } 3 \\
\text { months } \\
\text { PO }\end{array}$ & $\begin{array}{c}\text { At } 6 \\
\text { months } \\
\text { PO }\end{array}$ & $\begin{array}{c}\text { At } 12 \\
\text { months } \\
\text { PO }\end{array}$ & $\begin{array}{c}\text { At } 3 \\
\text { months } \\
\text { PO }\end{array}$ & $\begin{array}{c}\text { At 6 } \\
\text { months } \\
\text { PO }\end{array}$ & $\begin{array}{c}\text { At } 12 \\
\text { months } \\
\text { PO }\end{array}$ & $\mathbf{F}$ & lue \\
\hline IPSS & \pm 4.36 & $\begin{array}{l}11.1 \mathrm{a} \\
\pm 7.9\end{array}$ & $\begin{array}{r}9.86 \mathrm{a} \\
\pm 5.34\end{array}$ & $\begin{array}{l}8.8 \mathrm{a} \\
\pm 4.0\end{array}$ & $\begin{array}{l}10.52 \mathrm{ab} \\
\pm 7.63\end{array}$ & $\begin{array}{l}11.0 \mathrm{ac} \\
\pm 5.25\end{array}$ & $\begin{array}{l}9.20 \mathrm{ad} \\
\pm 4.26\end{array}$ & 7.322 & $1 * *$ \\
\hline QoL & $\begin{array}{c}4.46 \\
\pm 1.16\end{array}$ & $\begin{array}{c}2.7 \mathrm{a} \\
\pm 1.36\end{array}$ & $\begin{array}{r}1.9 \mathrm{a} \\
\pm 1.0\end{array}$ & $\begin{array}{r}1.7 \mathrm{a} \\
\pm 0.8\end{array}$ & $\begin{array}{l}2.72 \mathrm{a} \\
\pm 1.56\end{array}$ & $\begin{array}{l}1.84 \mathrm{a} \\
\pm 0.98\end{array}$ & $\begin{array}{l}1.64 \mathrm{a} \\
\pm 0.75\end{array}$ & 6.664 & $<0.001 * *$ \\
\hline Qmax & $\begin{array}{c}7.60 \\
\pm 2.80\end{array}$ & $\begin{array}{l}17.3 \mathrm{a} \\
\pm 0.9\end{array}$ & $\begin{array}{l}17.1 \mathrm{a} \\
\pm 0.8\end{array}$ & $\begin{array}{l}17.1 \mathrm{a} \\
\pm 0.8\end{array}$ & $\begin{array}{l}17.40 \mathrm{a} \\
\pm 0.84\end{array}$ & $\begin{array}{l}17.37 \mathrm{a} \\
\pm 0.91\end{array}$ & $\begin{array}{l}17.37 \mathrm{a} \\
\pm 0.93\end{array}$ & 4.047 & $<0.001 * *$ \\
\hline PVK & $\begin{array}{c}324.30 \\
\pm 167.50\end{array}$ & $\begin{array}{l}85.6 \mathrm{a} \\
\pm 40.7\end{array}$ & $\begin{array}{l}59.0 \mathrm{a} \\
\pm 34.0\end{array}$ & $\begin{array}{l}48.5 \mathrm{a} \\
\pm 29.0\end{array}$ & $\begin{array}{r}62.72 \mathrm{a} \\
\pm 38.65\end{array}$ & $\begin{array}{l}32.60 \mathrm{a} \\
\pm 20.87\end{array}$ & $\begin{array}{c}44.0 \mathrm{a} \\
\pm 27.30\end{array}$ & 5.164 & $<0.001 * *$ \\
\hline
\end{tabular}

Using: One Way Analysis of Variance; **p-value $<0.001 \mathrm{HS}$

Post HOC:

a: Significant difference with preoperative

b: Significant difference with At 3 months PO without retention

c: Significant difference with At 6 months PO without retention

d: Significant difference with At 12 months PO without retention

At 3 months postoperatively, IPSS was significantly lower in patients with retention; while at 6 and 12 months, the IPSS was significantly lower in patients without retention. On the other side, there was no significant difference between both groups regarding Qmax (Table 4).

Table (4): Relation between preoperative retention and postoperative IPSS score and Qmax

\begin{tabular}{|c|l|c|c|c|}
\hline \multicolumn{2}{|c|}{ Duration } & \multirow{2}{*}{ At 3 months PO } & At 6 months PO & At 12 months PO \\
\hline \multirow{3}{*}{ IPSS } & Without retention & $11.1 \pm 7.9$ & $9.86 \pm 5.34$ & $8.8 \pm 4.0$ \\
\cline { 2 - 5 } & With retention & $10.52 \pm 7.63$ & $11.0 \pm 5.25$ & $9.20 \pm 4.26$ \\
\cline { 2 - 5 } & P value & $<\mathbf{0 . 0 0 1} *$ & $<\mathbf{0 . 0 0 1 *}$ & $<\mathbf{0 . 0 0 1 *}$ \\
\hline \multirow{3}{*}{ Qmax } & Without retention & $17.40 \pm 0.84$ & $17.37 \pm 0.91$ & $17.37 \pm 0.93$ \\
\cline { 2 - 5 } & With retention & $17.30 \pm 0.9$ & $17.10 \pm 0.8$ & $17.10 \pm 0.8$ \\
\cline { 2 - 5 } & P value & $>0.05$ & $>0.05$ & $>0.05$ \\
\hline
\end{tabular}

\section{DISCUSSION}

In the present study, age ranged from 55 to 80 years; the mean age was $66.28 \pm 6.19$ years. The majority of patients $(58.0 \%)$ were in the age group from 61 to 70 years. The presenting symptoms were in the form of obstructive symptoms in $50.0 \%$ of patients and refractory retention in $50.0 \%$. Hypertension was reported in $70 \%$, diabetes mellitus in $10 \%$, ischemic heart disease (IHD) in $4 \%$ and liver disease in $22 \%$ of the patients. The operative time ranged from 60 to 120 minutes; the mean \pm SD values were $94.18 \pm 18.54$ minutes. In contradiction to results of the present work, Bogdan et al. 
(2011) has demonstrated in their study that the mean operative time was 52.1 and 55.6 minutes in the TURis and TURP group respectively. In addition, they demonstrated that the mean operative time in the PKVP group was 39.7 minutes. Furthermore, Oliver et al. (2010) stated that the mean operative time was 61 minutes. Komura et al. (2014) reported a mean operative time of 79.5 minutes. These differences are due to the inclusion of prostate size of more than 60 grams in the present study. The irrigation volume ranged from 10 to 40 liters; the mean values \pm SD were $25.34 \pm 7.86$. The results of the present work came in agreement with Lee et al. (2011) who reported that the mean irrigation volume was $31.5 \pm 3.37$ liters. Intraoperative complications were encountered in two patients (false passage in one patient which managed immediately by passing on a guide wire to the bladder and complete the procedure, and other one converted to open surgery to drain intra-abdominal collection at the end of the procedure and put a drain, urethral catheter was left for 7 days and a cystogram was done before its removal).

In the present work, early postoperative complications were in the form of retention in 4\%, temporary incontinence in $4 \%$, dysuria (irritative symptoms) in $70 \%$ which improved by time and infection in $6 \%$ of patients. Dysuria was the most common early postoperative complications $70 \%$ and none of these complications were observed after 6th month post-operative. Otsuki et al. (2012) reported that gross hematuria requiring bladder irrigation with re-catheterization was noted in $4.7 \%$. Acute urinary retention in $5.7 \%$ was relieved with a transient urethral catheter.
Irritative symptoms after catheter removal occurred in $11.2 \%$ of patients. Persistent perineal or urethral pain was present in $2.8 \%$. $7.5 \%$ with urethral stricture underwent urethral dilation 1-4 months after surgery. Late postoperative complications were reported in $4 \%$, presented with stricture urethra while the other presented with obstructing residual adenoma that needed retreatment. Stricture urethra was encountered in $2 \%$. The reported prevalence of urethral strictures after TURP was $9.8 \%$, and the causes are multifactorial. In the present work, the duration of hospital stay ranged from 3 to 4 days, while the urethral catheter duration ranged from 2 to 5 days. These results were comparable to Otsuki et al. (2012) who reported that the mean catheterization and postoperative hospitalization time was 2.08 days and 3.54 days, respectively. The postoperative stay of 3.56 days was slightly longer than that previously reported (Geavlete et al., 2010).

In the present work, preoperative voiding residual urine ranged from 70 to $600 \mathrm{ml}$; and there was statistically significant decrease at 3,6 and 12 months when compared to preoperative values. Zhigang et al. (2010) demonstrated that, in patients who underwent TURP, the mean PVRU decreased by $85.9 \mathrm{ml}$ and $88.2 \mathrm{ml}$ at 3 and 6 months respectively. Oliver et al. (2010) demonstrated that, in patients who underwent TURIS, the mean PVRU decreased by $130 \mathrm{ml}$ and $131 \mathrm{ml}$ at 3 and 6 months respectively. Our results were comparable to those mentioned by Singhania et al. (2010), and Giulianelli et al. (2013) who concluded that there was a significant improvement in their bipolar groups regarding to IPSS, Qmax, and 
PVR urine volume after 1 and 3 months postoperatively; when compared with baseline values. They also reported better improvements after 3 months than after 1 month. Our study revealed that, preoperative Q max ranged from 3.4 to 13 and there was statistically significant increase at 3, 6 and 12 months when compared to preoperative values. These results are comparable to $\mathrm{Xu}$ et al. (2018) who reported that there was significant improvement in Qmax immediately after the surgery and also during the follow-up period. In addition, Zhigang et al. (2010) reported that the mean Qmax has improved by $15.5 \mathrm{ml} / \mathrm{sec}$ and $12.8 \mathrm{ml} / \mathrm{sec}$ at 3 and 6 months respectively. Also, Oliver et al. (2010) demonstrated that the mean Qmax in patients who underwent PKVP has improved by $11.9 \mathrm{ml} / \mathrm{sec}$ and $11.5 \mathrm{ml} / \mathrm{sec}$ at 3 and 6 months respectively. There was no significant difference between postoperative and preoperative value of serum potassium and chloride. On the other hand, postoperative sodium increased when compared to corresponding preoperative values, while postoperative hemoglobin and hematocrit concentration decreased postoperatively when compared to corresponding preoperative values. These results were in contradiction to Otsuki et al. (2012) who reported that, there was no significant difference seen between the preoperative and postoperative serum sodium level. This could be explained by different sample size and selection criteria, as they work in all volumes of the prostate, while our study included only cases with prostate size $>60 \mathrm{ml}$.

In the present work, none of the patients complained of TUR syndrome which was due to Na deficiency, as $\mathrm{Na}$ did not decrease in the present study but it increased with no significant clinical impaction, and this could be explained by longer operative time with increase in irrigation fluid (saline). Oliver et al. (2010) demonstrated a mean decrease of $\mathrm{Na}$ in patients who underwent PKVP by $0.7 \mathrm{mEq} / 1$ and none of them was complicated with TUR syndrome. Also, Bogdan et al. (2011) demonstrated in their study that none of the patients in the PKVP group have experienced TUR syndrome.

Zhigang et al. (2010) demonstrated in their trial that the mean decrease in $\mathrm{Hb}$ in the TURP group was $1.88 \mathrm{gm} / \mathrm{dl}$. In another study conducted by Brathwaite et al. (2006) patients who underwent TURP had a decrease in $\mathrm{Hb}$ by $1.39 \mathrm{gm} / \mathrm{dl}$. In addition, Bogdan et al. (2011) in their study demonstrated that the mean decrease in $\mathrm{Hb}$ in the TURP group was $1.6 \mathrm{gm} / \mathrm{dl}$ while in the TURis group was $1.2 \mathrm{gm} / \mathrm{dl}$. Furthermore, Oliver et al. (2010) demonstrated that the mean drop of $\mathrm{Hb}$ in the patients who underwent PKVP was $1.1 \mathrm{gm} / \mathrm{dl}$. On the other side, Bogdan et al. (2011) demonstrated in their trial that the mean decrease in $\mathrm{Hb}$ in the PKVP group was $0.5 \mathrm{gm} / \mathrm{dl}$. The difference in the present work is $0.85 \mathrm{~g} / \mathrm{dl}$ which is in accordance with reported ranges.

In the present study, preoperative quality of life index ranged from 3 to 6 . At 3 months postoperatively, the index ranged from 1 to 6 , while at 6 months postoperatively, it ranged from 1- 4, and at 12 months postoperatively ranged from 1-4. There was a statistically significant decrease of QoL index at 3, 6, 12 months when compared to preoperative values. Similarly, there was a statistically 
significant decrease of international prostate symptoms score (IPSS) at 3, 6 and 12 months postoperatively when compared to preoperative values. These results were comparable to those reported by Otsuki et al. (2012) who reported that clinical improvements at 1 month were obvious for every item. Moreover, the subjective scores had improved and the prostate volume decreased significantly at 1-3 months in every group. A stepwise decrease was observed in the IPSS, QOL score, and prostate volume.

From our point of view, we believe that the lower incidence of intra- and postoperative complications may be due to several factors: 1) Better hemostatic effect of the bipolar system allowed less intraoperative and postoperative bleeding; 2) the clearer vision obtained due to the use of normal saline as an irrigant; 3 ) the higher resection speed allows shorter resection time and higher resection ratio, which in turn decreased the reoperation rate; 4) the use of normal saline as an irrigant has eliminated the risk of dilutional hyponatremia and minimized the time limit risk factor and hence allowed more comfortable and precise resection of most of the adenoma, reducing the risk of leaving residual adenoma, which in turn reduced the reoperation rate.

\section{CONCLUSION}

TURis is an excellent treatment option for bladder outlet obstruction due to $\mathrm{BPH}$ because of its excellent efficacy that is similar to but less invasive than TURP. Irritative symptoms were frequent and notable complications of TURis.

\section{REFERENCES}

1. Bodgan, Georgescu, D., Multescu, R., Stanescu, F., Jecu, M., and Geavlete, P. (2011): Bipolar plasma vaporization vs monopolar and bipolar TURP-a prospective, randomized, long-term comparison. Urology, 78(4), 930-935.

2. Cao J, Sheng X, Ding Y, Zhang $L$ and Lu X. (2019): Effect of warm bladder irrigation fluid for benign prostatic hyperplasia patients on perioperative hypothermia, blood loss and shiver: A meta-analysis. Asian Journal of Urology, 6: 183-191.

3. Cornu JN, Ahyai S, Bachmann A, de la Rosette J, Gilling $P$, Gratzke $\mathrm{C}$ and Madersbacher S (2015): A systematic review and meta-analysis of functional outcomes and complications following transurethral procedures for lower urinary tract symptoms resulting from benign prostatic obstruction: an update. European Urology, 67(6): 1066-1096.

4. Geavlete B, Multescu $\mathbf{R}$ and Dragutescu $M$ (2010): Transurethral resection (TUR) in saline plasma vaporization of the prostate vs standard TUR of the prostate: "the better choice" in benign prostatic hyperplasia? BJU Int., 106:1695-1699.

5. Giulianelli $\mathbf{R}$, Albanesi $\mathbf{L}$ and Attisani $\mathbf{F}$ (2013): Comparative randomized study on the efficaciousness of endoscopic bipolar prostate resection versus monopolar resection technique 3-year follow-up. Arch Ital Urol Androl, 85:86-91.

6. Han HH, Ko WJ, Yoo TK, Oh TH, Kim DY, Kwon DD and Jung TY (2014): Factors associated with continuing medical therapy after transurethral resection of prostate. Urology, 84(3): 675-680.

7. Komura K, Inamoto T, Takai T, Uchimoto T, Saito $K$ and Tanda N (2014): Could transurethral resection of the prostate using the TURis system take over conventional monopolar transurethral resection of the prostate? A randomized controlled trial and midterm results Urology, 84(2):405-11.

8. Lee Y T, Ryu Y W, Lee D M, Park S W, Yum S H and Han J H (2011): Comparative 
Analysis of the Efficacy and Safety of Conventional Transurethral Resection of the Prostate, Transurethral Resection of the Prostate in Saline (TURIS), and TURISPlasma Vaporization for the Treatment of Benign Prostatic Hyperplasia: A Pilot Study. Korean Journal of Urology, 52(11):763-8.

9. Oelke M, Bachmann A and Descazeaud A (2013): EAU guidelines on the treatment and follow-up of non-neurogenic male lower urinary tract symptoms including benign prostatic obstruction. Eur Urol., 64:118-140.

10. Oliver, Schlenker, B., Gratzke, C., Tilki, D., Riecken, M., Stief, C. and Bachmann, A. (2010): Plasma vaporisation of the prostate: initial clinical results. European Urology, 57(4): 693-698.

11. Otsuki H, Kuwahara Y, Kosaka T, Tsukamoto T, Nakamura K, Shiroki R and Hoshinaga K. (2012): Transurethral Resection in Saline Vaporization: Evaluation of Clinical Efficacy and Prostate Volume. Urology, 79: 665-669.

12. Reich O, Schlenker B and Gratzke C (2010): Plasma vaporization of the prostate: initial clinical results. Eur Urol., 57:693-697.

13. Singhania $P$, Nandini $D$, Sarita F, Hemant $P$ and Hemalata I (2010): Transurethral resection of prostate: a comparison of standard monopolar versus bipolar saline resection. Int Braz J Urol, 36:183-189.
14. Teng J, Zhang D, Li Y, Yin L, Wang K, Cui $X$ and Xu D (2013): Photoselective vaporization with the green light laser vs transurethral resection of the prostate for treating benign prostate hyperplasia: a systematic review and meta-analysis. BJU international, 111(2): 312-323.

15. Xu P, Xu A, Chen B, Zheng $S$ and $X u Y$ (2018): Bipolar transurethral enucleation and resection of the prostate: Whether it is ready to supersede TURP? Asian Journal of Urology, 5: 48e54.

16. Zhigang Zhao, Zeng, G., Zhong, W., Mai, Z., Zeng, S. and Tao, X. (2010): A prospective, randomised trial comparing plasmakinetic enucleation to standard transurethral resection of the prostate for symptomatic benign prostatic hyperplasia: three-year follow-up results. European Urology, 58(5): 752-758

17. Zhong J, Feng $Z$, Peng $Y$ and Liang $H$. (2019): A Systematic Review and Metaanalysis of Efficacy and Safety Following Holmium Laser Enucleation of Prostate and Transurethral Resection of Prostate for Benign Prostatic Hyperplasia. Urology, 131:14-20. 


\section{الاستئصال ثنائي القطبية لأورام البروستاتا الحميدة أكبر من 60 سم3: الأمان والفياعة الأبروينية}

السيد الشهاوى، على فرج، أحمد عبد الرحيمث، جمال الشيال

قسم جراحة المسالك البولية، كلية الطب، جامعة الأزهر (القاهرة* ودمياط)

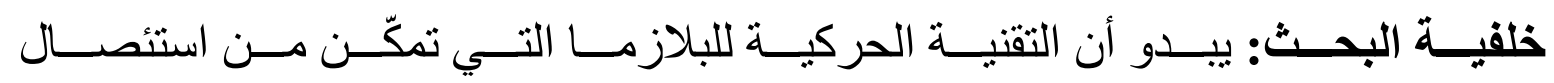

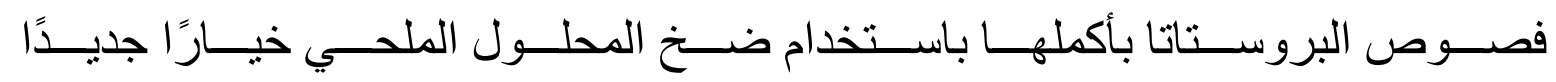

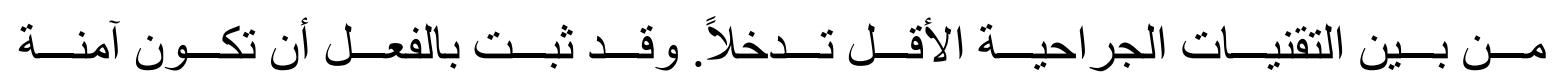
وفعالة لعلاج انسداد تدفق المثانة الناتج عن التضخم الحميد للبروستاتا.

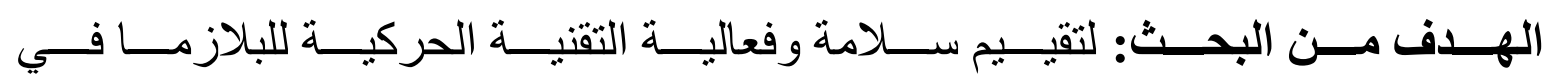

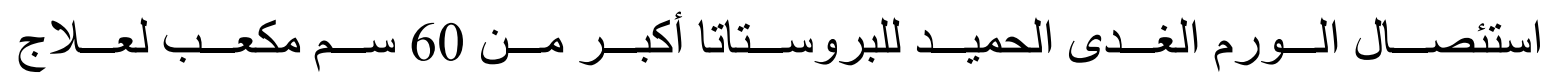

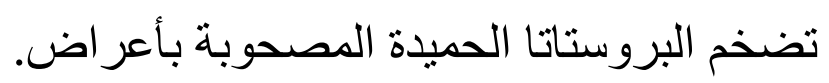

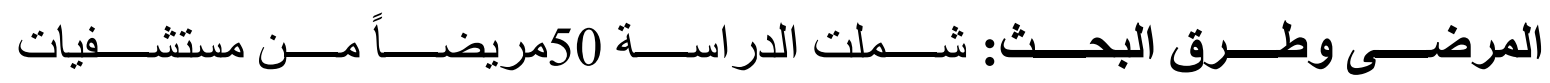

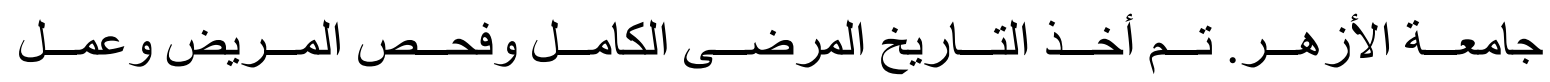

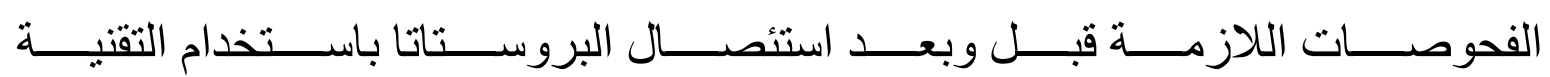
الحركية للبلازما.

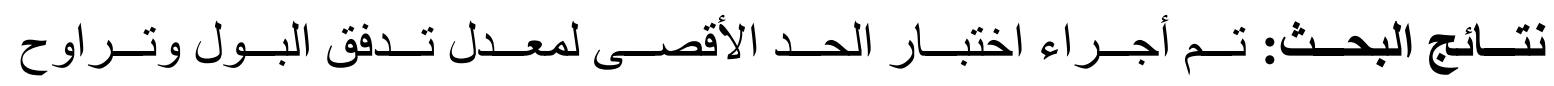

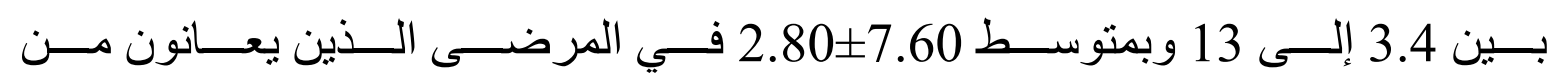

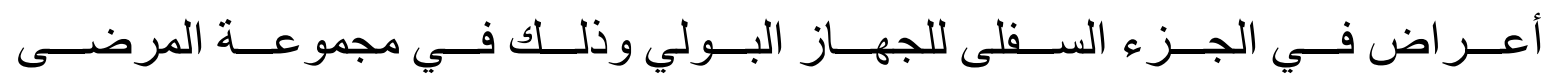

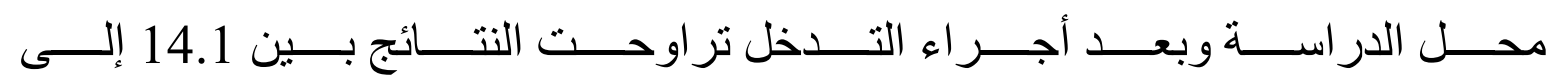

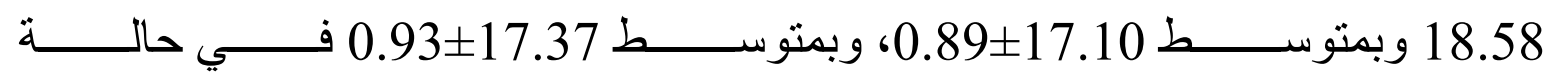

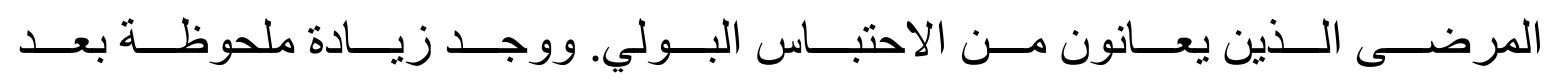

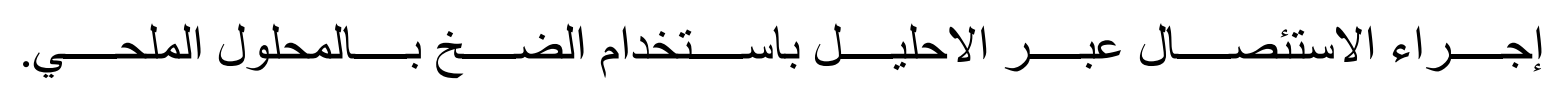

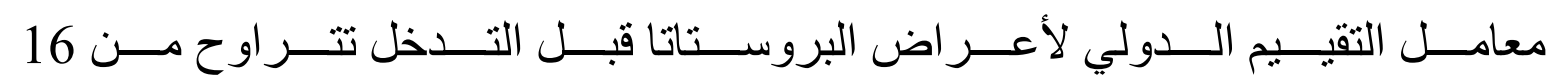




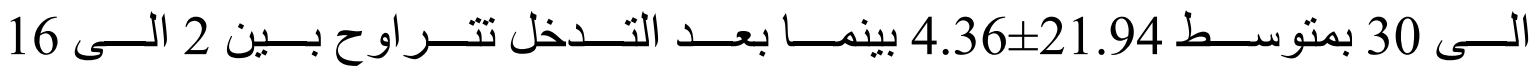

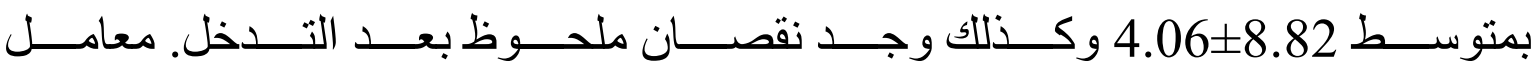

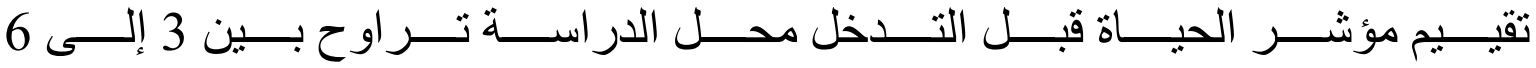

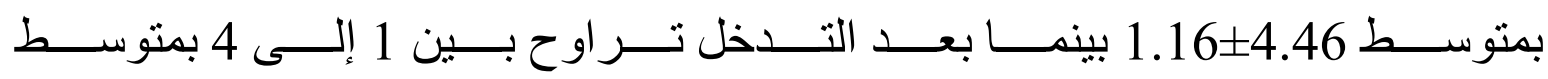

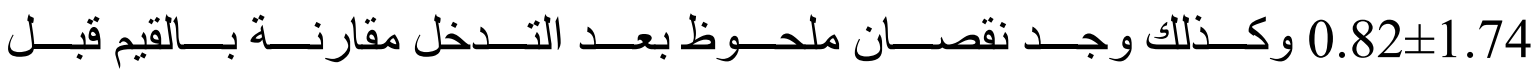
الاجر اء الجديد المتبع في الدراسة.

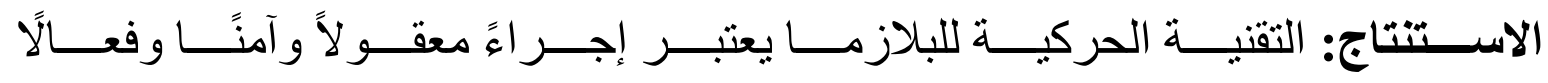
لعلاج تضخم البروستاتا الحميد. 